\title{
Desain Game Edukasi Berbasis Android pada Materi Transformasi
}

\author{
Cut Eka Fitriana*, Maimunah, Yenita Roza \\ PPs Pendidikan Matematika, FKIP Universitas Riau \\ *Corresponding Author. Email: cut.eka7964@grad.unri.ac.id
}

\begin{abstract}
The purpose of this research is to produce a product in the form of media game android based education on transformation material. This research uses research and development $(R \& D)$. with model procedure Four $D$ (4-D). This research was conducted at one of the state junior high schools in Bengkalis Regency. The data collection technique was in the form of a questionnaire using a Likert scale. The data analysis technique was analyzed by transforming the average scale into qualitative sentences. Research This results indesign in game adventure educational trans go an android-based accordance with the analysis of the needs and problems encountered at school. The results of the feasibility study show the validity of $86 \%$ with very valid criteria. In conclusion, products game android based education on transformation material are feasible and can be implemented in mathematics learning.
\end{abstract}

\begin{abstract}
Abstrak: Tujuan dari penelitian ini untuk menghasilkan produk berupa media game edukasi berbasis android pada materi transformasi. Penelitian ini menggunakan metode penelitian dan pengembangan $(R \& D)$ dengan prosedur model Four D (4-D). Penelitian ini dilakukan di salah satu SMP Negeri di Kabupaten Bengkalis. Teknik pengumpulan data berupa angket dengan menggunakan skala likert. Teknik analisis data dianalisis dengan cara mentransformasi skala rata-rata kedalam kalimat bersifat kualitatif. Penelitian ini menghasilkan desain game edukasi petualangan trans go berbasis android sesuai dengan analisis kebutuhan serta permasalahan yang ditemui di sekolah. Hasil studi kelayakan menunjukkan validitas $86 \%$ dengan kriteria sangat valid. Kesimpulannya, produk game edukasi berbasis android pada materi transformasi layak dan dapat diimplementasikan pada pembelajaran matematika.
\end{abstract}

\section{Article History}

Received: 18-12-2020

Revised: 25-01-2021

Accepted: 20-04-2021

Published: 07-06-2021

\section{Key Words:}

Learning Media,

Educational Game,

Android,Transformation,

Mathematic.

\section{Sejarah Artikel}

Diterima: 18-12-2020

Direvisi: 25-01-2021

Disetujui: 20-04-2021

Diterbitkan: 07-06-2021

\section{Kata Kunci:}

Media Pembelajaran,

Game Edukasi, Android,

Transformasi, Matematis.

How to Cite: Fitriana, C., Maimunah, M., \& Roza, Y. (2021). Desain Game Edukasi Berbasis Android pada Materi Transformasi. Jurnal Kependidikan: Jurnal Hasil Penelitian dan Kajian Kepustakaan di Bidang Pendidikan, Pengajaran dan Pembelajaran, 7(2), 297-305. doi:https://doi.org/10.33394/jk.v7i2.3268

d. https://doi.org/10.33394/jk.v7i2.3268

This is an open-access article under the CC-BY-SA License.

\section{Pendahuluan}

Perkembangan era globalisasi menyebabkan teknologi mengalami perkembangan yang begitu cepat, terutama dalam bidang ilmu pengetahuan serta teknologi sehingga membuka pintu kemudahan dunia dalam menghadapi perubahan-perubahan yang berubah begitu cepat dari sebelumnya. Perkembangan ilmu pengetahuan serta teknologi juga berdampak kepada pendidikan. Pendidikan sangat memegang peranan penting dalam mengembangkan ilmu pengetahuan serta teknologi. pendidikan abad 21 sudah semestinya berbasis teknologi guna menyeimbangkan dengan perkembangan era globalisasi. Sugiyarti, Arif, \& Mursali (2018) menyatakan pada abad 21 peserta didik sudah harus terbiasa dengan kecakapan hidup abad 21 guna untuk menyesuaikan dengan keadaan era milineal dengan cara pembelajaran yang berbasis teknologi. Perkembangan ilmu pengetahuan dan teknologi (IPTEK) menjadikan masing-masing individu harus mempunyai kemampuan bersaing yang tinggi. Trilling dan Fadel (dalam Abidin, 2014) menyatakan terdapat tiga fokus keterampilan 
utama pada abad 21 yaitu: pertama merupakan keterampilan berinovasi serta belajar, kedua merupakan keterampilan dalam menguasai informasi, teknologi dan media, serta kemampuan ketiga merupakan keterampilan berkarir dan berkehidupan.

Berkembangnya IPTEK juga menuntut guru untuk dapat menghasilkan media pembelajaran berbasis teknologi. Kehadiran media pembelajaran sangatlah membantu dalam proses belajar peserta didik. Media pembelajaran menurut Wahidin \& Syaefuddin (2018) adalah sebuah media yang dapat merangsang pikiran serta dapat menyalurkan pesan, kemauan dan perasaan peserta didik agar peserta didik semangat untuk melakukan pembelajaran. Media pembelajaran menurut Suryani (dalam Angriani et al., 2020) bertujuan sebagai pembawa dan pemberi informasi antara penerima dan sumber informasi. Hasbullah (dalam Martha Rusmana \& Mila Kurniawarsih, 2020) menyebutkan bahwa media pembelajaran matematika adalah sarana pembelajaran matematika yang dimanfaatkan untuk mempelajari, memahami, menyajikan, dan mempermudah dalam proses belajar mengajar matematika, hal ini disebabkan matematika yang bersifat abstrak, bagi peserta didik SMP berfikir secara abstrak merupakan hal yang sulit. Oleh karena itu, diperlukan suatu media yang bisa membantu peserta didik dalam mempelajari hal yang abstrak, dalam menggunakan media pembelajaran, bahan belajar yang abstrak dapat dikongkritkan pada pembelajaran Kuswanto \& Radiansah (2018). Perkembangan teknologi informasi dan komunikasi dibidang pendidikan dapat mengubah pembelajaran yang abstrak menjadi kongkrit melalui media pembelajaran berbasis android.

Android adalah generasi baru pada fitur mobile yang betul-betul terbuka untuk melakukan sebuah pengembangan yang sesuai dengan keinginan yang ingin dikembangkan bagi para pengembang Abdilah, Mardiyani, \& Nawawi (2018). Android adalah suatu sistem operasi untuk perangkat mobile berbasis linux yang terdiri dari middleware, aplikasi, serta sistem operasi. Android menyajikan platform terbuka untuk para pengembang dalam membuat aplikasi mereka sendiri Erri Wahyu Puspitarini, Dian Wahyu Putra (2016). Sementara itu Satyaputra dan Aritonang (dalam Putri \& Sumbawati, 2017) mendefinisikan android sebagai suatu sistem operasi yang digunakan oleh tablet dan smartphone. Sistem operasi dapat diilustrasikan sebagai jembatan antara device (peranti) dan penggunanya, sehingga pengguna bisa berinteraksi dengan device nya serta menjalankan aplikasi-aplikasi yang tersedia pada device. Pemakaian smartphone tengah terkenal di dunia bahkan dikalangan pelajar, dengan munculnya smartphone dapat memberikan manfaat serta memberi kemudahan untuk penggunaannya. Dengan seluruh fasilitas yang disediakan oleh smartphone tersebut, berbagai aktifitas dapat dilakukan oleh penggunanya, seperti aktifitas bermain game offline atau game online, serta dapat dimanfaatkan dalam hal yang bersifat sosial ataupun bisnis, seperti membaca berita, pengiriman surat menggunkan e-mail, melakukan transaksi menggunakan fasilitas e-commerce dan lainnya Doni (2017).

Namun, dibalik kelebihan dari smartphone terdapat kekurangannya, yaitu peserta didik sering menyalah gunakan smartphonenya untuk hal yang tidak berguna, seperti bermain game. Perihal ini dapat dilihat dari hasil penelitian yang dilakukan oleh Santoso (dalam (Sejati \& Koeswanti, 2020) yang menjelaskan bahwa pada tahun-2015 Indonesia menempati posisi ke-24 serta tahun-2017 Indonesia menempati posisi ke-16 dari dunia yang menggunakan serta menggemari game. Hal ini menunjukkan bahwa semua golongan yang terdapat di Indonesia gemar bermain game. Selain itu, Munculnya bermacam permainan game online, kebanyakan dari pihak pelajar, mahasisiwa ataupun masyarakat karena pada umunya mereka masih ada yang belum mengetahui secara spesifik dampak permainan game online Gurusinga (2020). Dari fenomena yang terjadi, pendidik dapat menggunakan game untuk dikembangkan menjadi sebuah media pembelajaran. Sejalan dengan penelitian yang 
dilakukan oleh Virginiawan \& Sitohang (2020) dan Safitri, Pujiastuti, \& Sudiana (2020). Game edukasi menurut Suryawirawati (dalam Naimah, Winarni, \& Widiyawati, 2019) adalah sebuah media permainan yang memuat cakupan materi pembelajaran yang dapat dimanfaatkan untuk mengarahkan serta mendidik peserta didik pada proses pembelajaran yang menyenangkan, pembelajaran dengan menggunakan konsep belajar sembari bermain, membuat peserta didik belajar lebih aktif dalam proses pembelajaran. Penggunaan game dalam proses belajar mengajar dapat merangsang peserta didik untuk belajar lebih aktif serta dapat menjadikan pembelajaran menjadi lebih santai. Adapun penelitian ini bertujuaan untuk menghasilkan media pembelajaran game edukasi matematis berbasis android pada materi transformasi.

\section{Metode Penelitian}

Penelitian ini menggunakan metode penelitian dan pengembangan $(R \& D)$. Sugiyono (2014) menyatakan penelitian dan pengembangan $(R \& D)$ merupakan metode penelitian yang dilakukan guna menghasilkan sebuah produk tertentu, serta menguji keefektifan produk. Dalam Prosedur penelitian menggunakan model pengembangan 4-D, model pengembangan 4-D merupakan model pengembangan yang terdiri dari 4 tahapan yaitu, tahap pendefinisian (Define), tahap perancangan (Design), tahap pengembangan (Develop), tahap penyebaran (Disseminate) Pada tahap ini peneliti mengembangkan produk hanya dibatasi pada tahap pendefinisian (Define) dan perancangan (Design). Metode ini dipilih dengan tujuan untuk menghasilkan sebuah produk media game edukasi berbasis android.

Tahap pertama adalah tahap pendefinisian (Define), pada tahap pendefinisian bertujuan untuk mendefinisi kebutuhan-kebutuhan yang diperlukan dalam proses pembelajaran dan mengumpulkan bermacam informasi yang berkaitan dengan media yang akan dikembangkan. Setelah mengetahui permasalahan dari tahap pendefinisian, tahap selanjutnya dilakukan perancangan (Design). Tahap perancangan ini bertujuan untuk merancang suatu media game edukasi berbasis android yang dapat digunakan dalam pembelajaran. Teknik pengumpulan data berupa angket dengan menggunakan skala likert. Teknik analisis data dianalisis dengan cara mentransformasi skala rata-rata kedalam kalimat bersifat kualitatif.

\section{Hasil Penelitian dan Pembahasan Tahap Define}

Tahap pengembangan diawali dengan melakukan analisis permasalahan yang dialami oleh peserta didik dan guru pada materi transformasi serta analisis kebutuhan dengan menganalisis keadaan bahan ajar yang digunakan di sekolah. Tujuannya agar diketahui bahan ajar yang mendukung proses pembelajaran di sekolah. Pada proses pembelajaran peserta didik mengalami kesulitan dalam menentukan dan memahami letak titik koordinat cartesius sehingga mengalami kesalahan dalam menentukan titik koordinat cartesius tersebut. Permasalahan lain yang ditemui adalah peserta didik kurang tertarik dalam pelajaran matematika yang monoton. Sehingga diperlukan suatu media pembelajaran yang bisa memberikan visualisasi dengan baik pada materi transformasi. Salah satu media pembelajaran yang dapat mengurangi kejenuhan terhadap pembelajaran matematika adalah menggunakan media pembelajaran game edukasi berbasis android. Melalui visualisasi yang menarik serta baik pada fitur android diharapkan aktivitas pembelajaran menjadi lebih mengasyikkan dan bermakna bagi peserta didik. Sejalan dengan pendapat Rusman, dkk yang menyatakan bahwa permainan sebagai media pembelajaran bisa menciptakan suasana pembelajaran menjadi lebih mengasyikkan serta dapat menegurangi kejenuhan terhadap 
informasi maupun materi yang disampaikan oleh guru kepada peserta didik Nugraha \& Hertanto (2017).

Analisis kurikulum dilakukan untuk mengetahui kurikulum yang digunakan di sekolah yang bersangkutan. Sehingga pengembangan yang dilaksanakan sesuai dengan kurikulum yang ada disekolah. Pada analisis kurikulum ini dilakukan dengan memutuskan serta menetapkan KD (Kompetensi Dasar) yang hendak dikemas pada game edukasi berbasis android. Pada game edukasi berbasis android dipilih KD (Kompetensi Dasar) 3.5. (Menjelaskan transformasi geometri (refleksi, translasi, rotasi, dan dilatasi) yang dihubungkan dengan masalah kontekstual) dan KD (Kompetensi Dasar) 4.5. (Menyelesaikan permasalahan kontekstual yang berkaitan dengan transformasi geometri (refleksi, translasi, rotasi, dan dilatasi)) pada kelas IX SMP/MTs.

Setelah melakukan analisis dari permasalahan, analisis kebutuhan serta analisis kurikulum selesai, maka hal berikutnya adalah menganalisis keperluan pada perangkat lunak yang digunakan dalam mendesain game edukasi berbasis android. Aplikasi yang digunakan untuk mengembangkan game edukasi berbasis android, yaitu: aplikasi Construct 2.

\section{Tahap Design}

Tahap desain game edukasi ini di rancang berdasarkan analisis yang telah dilakukan pada tahap sebelumnya. Tahapan dalam merancang desain game edukasi menggunakan aplikasi android dibagi menjadi dua yaitu, rancangan materi pembelajaran dan rancangan tampilan serta susunan game edukasi pada perangkat android. Uraian lebih lanjut mengenai rancangan game edukasi pada aplikasi android sebagai berikut.

\section{Rancangan materi pembelajaran}

Rancangan materi pembelajaran disusun berdasarkan analisis kurikulum yang telah dilakukan sebelumnya. Rancangan materi pada game edukasi berbasis android dirancang berdasarkan KD. 3.5. dan KD. 4.5. pada materi transformasi. Materi pembelajaran dibagi menjadi empat materi pokok, yaitu refleksi, translasi, rotasi, dan dilatasi. Materi transformasi pada game edukasi disusun dalam bentuk soal latihan yang terdapat dalam game.

\section{Rancangan tampilan serta susunan game edukasi}

Rancangan tampilan serta susunan game edukasi dimulai dengan menentukan ukuran baground, jumlah slide, pembuatan baground, pemilihan warna, menentukan jenis, warna, serta ukuran tulisan, pemilihan musik dan pemilihan animasi yang sesuai dengan materi pada game edukasi. Proses ini sepenuhnya dirancang pada Construct 2. Rancangan tampilan serta susunan game edukasi dibuat semenarik mungkin, dengan tujuan untuk memberikan kesan yang mengasyikkan bagi peserta didik dalam mempelajari matematika pada materi transformasi. Rancangan tampilan serta susunan yang akan dirancang pada game edukasi adalah sebagai berikut.

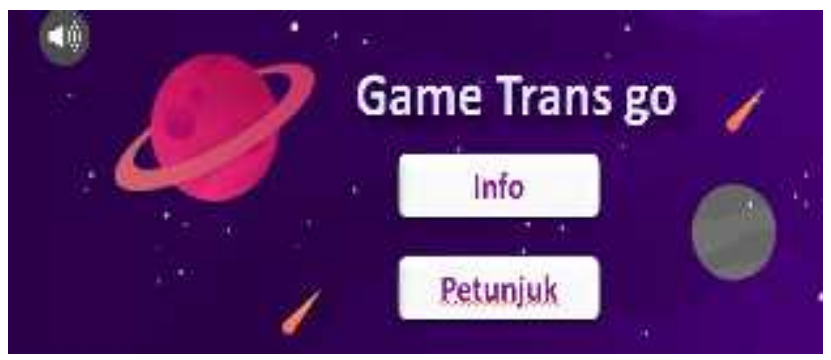

Gamar 1. Halaman Pilihan Menu

Pada halaman pilihan menu, peserta didik dapat memilih menu info, petunjuk, mulai, tombol keluar dan tombol menghidupkan dan mematikan suara. 


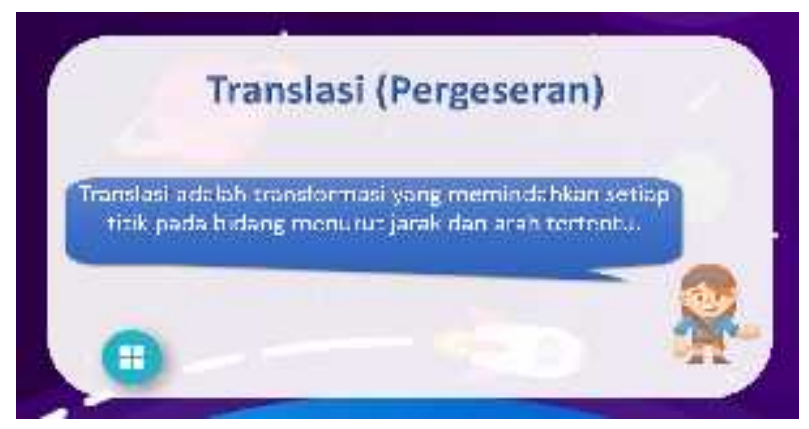

Gambar 2. Halaman Menu Info Game Edukasi

Pada gambar 2 diatas merupakan halaman menu info pada game edukasi yang berisikan materi pembelajaran geometri transformasi dan peserta didik juga dapat memilih tombol menu utama.
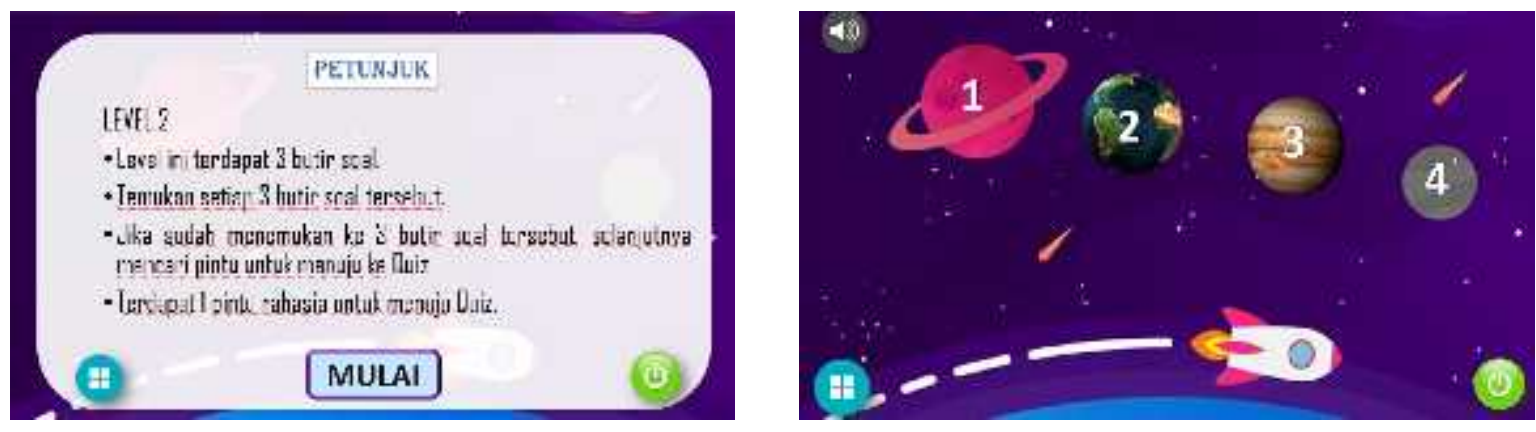

Gambar 3. Halaman Petunjuk dan halaman mulai Game Edukasi

Pada gambar 3 diatas merupakan tampilan petunjuk dan halaman mulai pada game edukasi. Halaman petunjuk terdiri dari aturan permainan, halaman menu, menu mulai, dan tombol keluar. Tampilan halaman mulai terdiri dari tombol level game edukasi, halaman menu, dan tombol keluar, pada tombol level game edukasi jika misi dilevel 1 belum selesai, maka level selanjutnya tidak akan bisa dibuka.

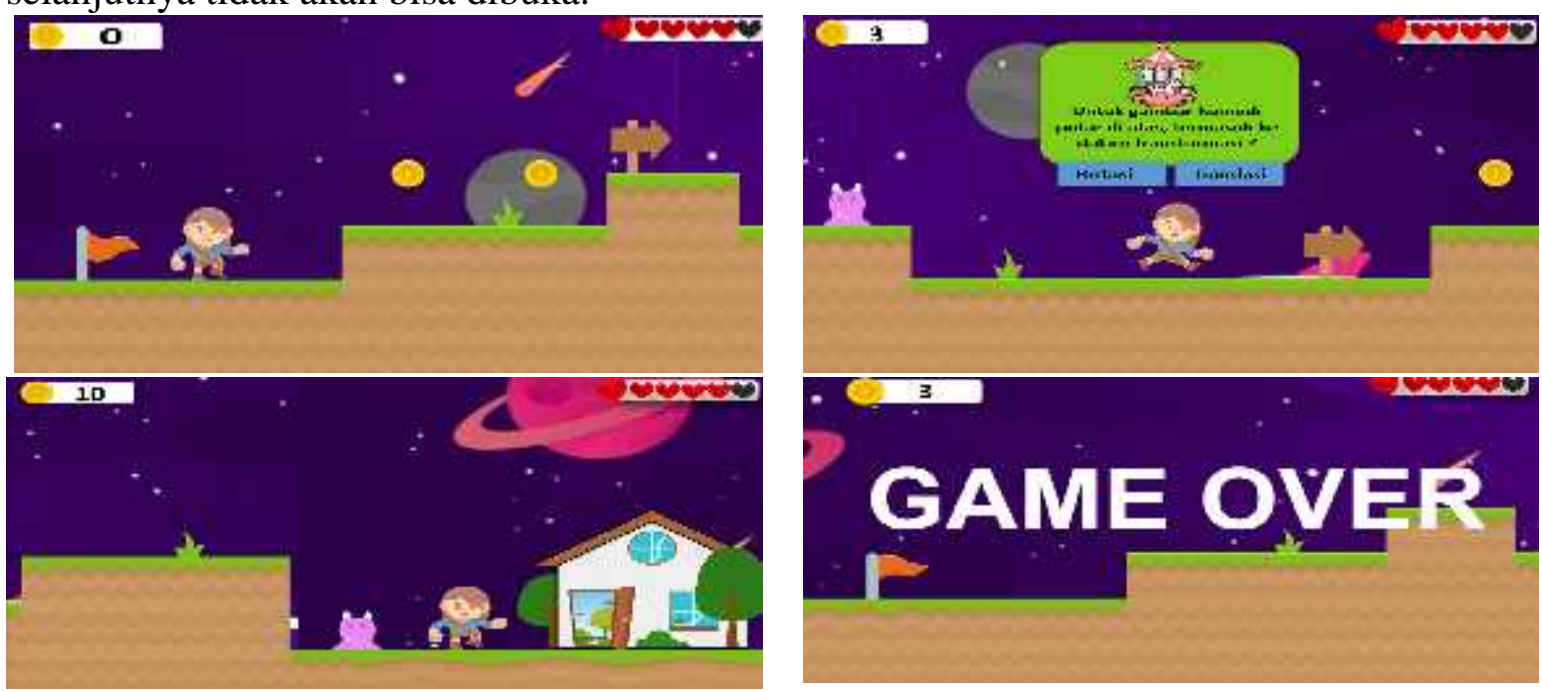

\section{Gambar 4. Halaman Game level 1}

Pada gambar 4 diatas merupakan tampilan game level 1, pada level 1 ini terdapat koin, musuh, dan tombol pertanyaan. level 1 ini peserta didik mengumpulkan koin sebanyak mungkin dan menjawab persoalan yang muncul. Jika peserta didik tidak bisa menjawab persoalan yang muncul, maka nyawa pada game edukasi akan berkurang dan jika jawaban benar maka poin akan bertambah, jika peserta didik menyentuh musuh (tumbuhan bergigi) 
maka nyawa pada game edukasi akan berkurang, jika peserta didik sampai menuju rumah, maka misi pada level 1 game edukasi selesai dan akan muncul halaman menu untuk melanjutkan ke level selanjutnya, serta jika nyawa peserta didik pada game edukasi telah habis, maka game akan berakhir.
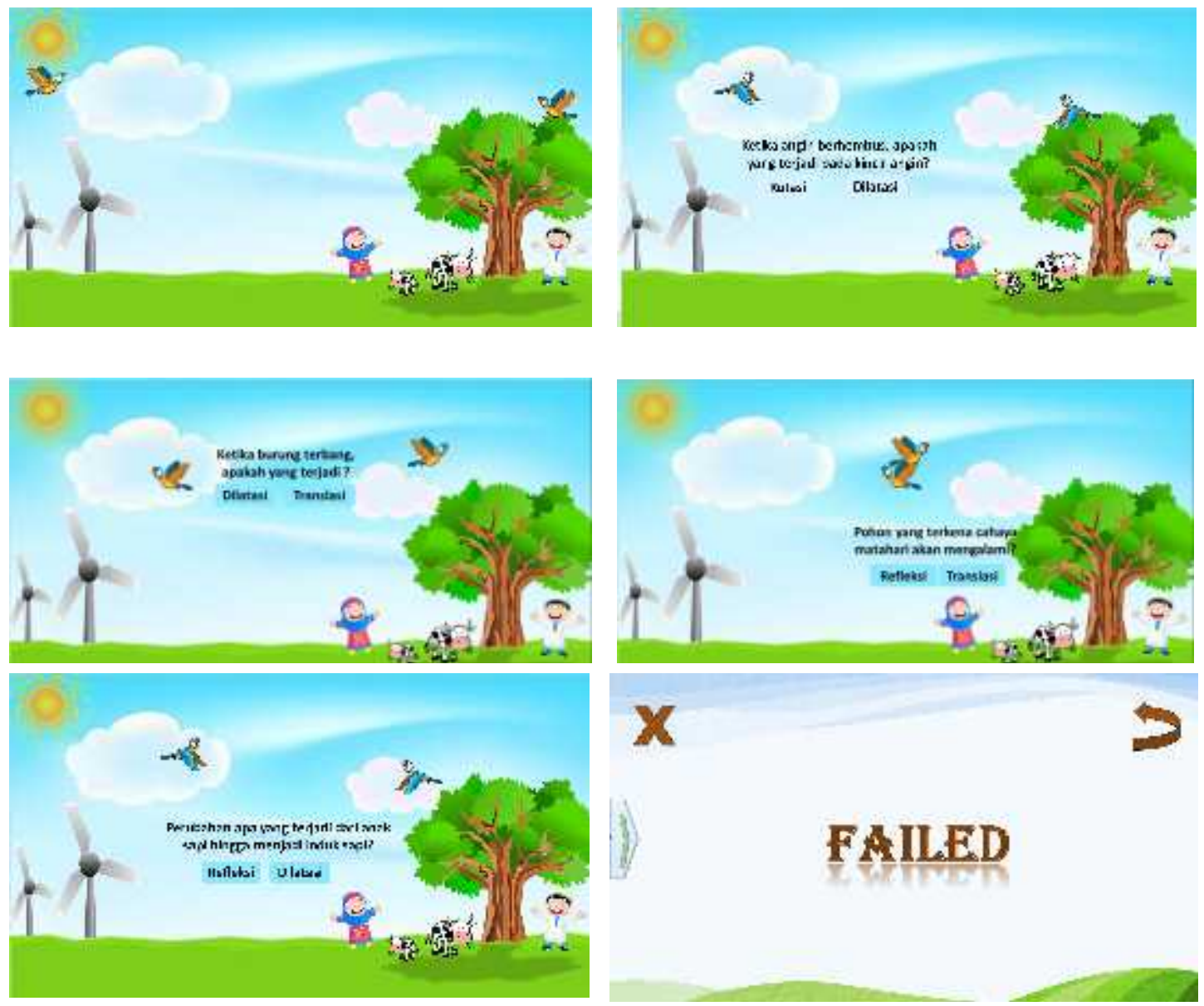

Gambar 5. Halaman Game level 2

Pada gambar 5 diatas merupakan tampilan game level 2, pada level 2 ini, apabila peserta didik menyentuh burung yang lagi bergerak maka akan muncul pertanyaan "ketika burung terbang, apakah yang terjadi?" selanjutnya peserta didik menjawab pertanyaan dengan jawaban yang dirasa benar, tetapi jika salah maka akan muncul halaman failed. Apaila peserta didik menyentuh kincir angina maka akan muncul pertanyaan "ketika angin berhemus, apakah yang terjadi pada kincir angina?" selanjutnya peserta didik menjawab pertanyaan dengan jawaban yang dirasa benar, tetapi jika salah maka akan muncul halaman failed. Begitu juga dengan pohon dan sapi, apaila tersentuh maka akan keluar pertanyaan. Dalam level 2 ini merupakan clue untuk melanjutkan game menuju level berikutnya dan pada level ini terdapat 2 jebakan (anak perempuan dan matahari) apabila peserta didik menekan jebakan tersebut maka permainan akan selesai. Selanjutnya pada level 2 ini juga terdapat menu rahasia untuk menuju level selanjutnya (anak laki-laki). Jika menu tersebut ditekan, maka langsung tiba di halam permainan level 3. Pada akhir games akan muncul halaman kuis yang berisikan 3 pertanyaan berbentuk objektif, lalu peserta didik memilih jawaban mana menurut peserta didik benar. Pada akhir kuis akan muncul skor peserta didik. Melalui games pada setiap level-level dan kuis guna untuk menambah wawasan peserta didik dan menjadikan pembelajaran matematika itu menjadi menyenangkan. 
Dalam proses desain game edukasi berbasis android ini terdapat saran-saran perbaikan dari validator seperti memuat aspek aplikasi dan materi. Desain game edukasi berbasis android yang dihasilkan sebagai draft awal telah melalui proses uji validasi oleh validator ahli yang mereview aspek isi, penyajian dan kegiatan pembelajaran. Hasilnya disajikan pada Tabel 1 berikut ini.

Tabel 1. Hasil Validasi Produk

\begin{tabular}{lcc}
\hline \multicolumn{1}{c}{ Perangkat } & Nilai Rata-Rata (\%) & Kriteria \\
\hline Silabus & $89 \%$ & Sangat Valid \\
RPP & $86 \%$ & Sangat Valid \\
Game Edukasi berbasis android & $83 \%$ & Valid \\
Rata-Rata & $86 \%$ & Sangat Valid \\
\hline
\end{tabular}

Berdasarkan Tabel 1 hasil validasi produk, menunjukkan bahwa persentase rata-rata hasil validasi atau kelayakan produk $86 \%$ dengan kriteria sangat valid. Hal ini berarti produk yang dikembangkan dapat diimplementasikan dalam pembelajaran.

Media pembelajaran game edukasi berbasis android dapat dimanfaatkan menjadi media pembelajaran untuk peserta didik SMP, hal ini dikarenakan perolehan hasil rata-rata kelayakan penerapan tersebut layak, peserta didik bisa mengevaluasi ilmunya dengan menjajaki permainan pada game edukasi berbasis android yang dikembangkan. Game edukasi berbasiskan android ini mempunyai manfaat yaitu bisa dipergunakan secara mandiri oleh peserta didik baik itu diluar sekolah ataupun di sekolah dikarena game edukasi trans go gampang diakses, cukup mendownload lewat WhatsApp maka bisa dimanfaatkan dengan praktis dan dapat di download melalui smartphone ataupun melalui PC. Media game edukasi berbasis android ini juga memfasilitasi ulasan serta di akhir evalausi terdapat hasil nilai evaluasi guna mengetahui seberapa pencapaian peserta didik dengan memanfaatkan media game edukasi berbasis android. Hal ini sejalan dengan hasil riset dari Muyaroah \& Fajartia, (2017) yang menunjukan proses belajar mengajar menggunakan media android bisa meningkatkan perolehan nilai belajar peserta didik. Penelitian ini didukung oleh penelitian yang dilakukan oleh Ramdani, Jufri, \& Jamaluddin (2020) yang menyatakan bahwa produk media berbasis android layak diimplementasikan dalam pembelajaran. Virginiawan \& Sitohang (2020) juga mengadakan penelitian game edukasi berbasis android yang menunjukkan efektifnya game edukasi berbasis android. Sejalan dengan penelitian Pratama \& Rahayu Sri Waskitoningtyas (2020) mendapatkan hasil dari rata-rata kelayakan media dari ahli sebesar $77,63 \%$ atau kriteria layak.

\section{Kesimpulan}

Berdasarkan hasil penelitian ini, diperoleh desain game edukasi petualangan trans go berbasis android sesuai dengan analisis kebutuhan serta permasalahan yang ditemukan di sekolah. Aplikasi didesain berdasarkan analisis permasalahan dan kebutuhan guru dan peserta didik pada materi transformasi kelas IX SMP/MTs. Desain game edukasi petualangan trans go berbasis android memperoleh hasil validitas $86 \%$ dengan kriteria sangat valid. Produk game edukasi berbasis android pada materi transformasi layak dan dapat diimplementasikan pada pembelajaran matematika.

\section{Saran}

Berdasarkan hasil penelitian ini, ada beberapa saran yang disampaikan yakni guru matematika dapat memilih media pembelajaran yang akan digunakan sesuai dengan materi pembelajaran, perkembangan ilmu pengetahuan dan teknologi, serta dapat memberdayakan kemampuan peserta didik sesuai dengan tuntutan perkembangan era globalisasi ini. 


\section{Daftar Pustaka}

Abdilah, A., Mardiyani, E., \& Nawawi, I. (2018). Aplikasi Komputer dan Smartphone Berbasis Android untuk Menangani Reservasi Hotel pada Citi Smart Hotel - BSD. Jurnal Tehnik Komputer, 4(2). https://doi.org/10.31294/jtk.v4i2.3597

Abidin, Y. (2014). Desain Sistem Pembelajaran dalam Konteks Kurikulum 2013. Bandung: PT Refika Aditama.

Angriani, A. D., Kusumayanti, A., Nur, F., Matematika, J. P., Islam, U., \& Alauddin, N. (2020). Pengembangan Media Pembelajaran Mathsc Berbasis Android Menggunakan App Inventor 2 Pada Materi Barisan Dan Deret AritmatikA. Jurnal Cendekia: Jurnal Pendidikan Matematika, 04(02), 926-938.

Doni, rohma F. (2017). Perilaku Penggunaan Smartphone Pada Kalangan Remaja. Journal Speed Sentra Penelitian Engineering Dan Edukasi, 9(2), 16-23.

Erri Wahyu Puspitarini, Dian Wahyu Putra, A. P. N. (2016). Game Edukasi Berbasis Android Sebagai Media Pembelajaran Untuk Anak Usia Dini. J I M P - Jurnal Informatika Merdeka Pasuruan, 1(1), 46-58. https://doi.org/10.37438/jimp.v1i1.7

Gurusinga, M. F. (2020). Hubungan Kecanduan Game Online dengan Pola Tidur pada remaja usia 16-18 tahun di SMAN 1 Deli tua. Journal Penelitian Medical, 2(2). Retrieved from http://ejournal.delihusada.ac.id/index.php/JPKM

Kuswanto, J., \& Radiansah, F. (2018). Media Pembelajaran Berbasis Android Pada Mata Pelajaran Sistem Operasi Jaringan Kelas XI. Jurnal Media Infotama, 14(01).

Martha Rusmana, I., \& Mila Kurniawarsih. (2020). Pengembangan Media Pembelajaran Komik Matematika Siswa Kelas Iv Sekolah Dasar Berbasis Budaya. Jurnal Lebesgue: Jurnal Ilmiah Pendidikan Matematika, Matematika Dan Statistika, 1(1), 39-48. https://doi.org/10.46306/lb.v1i1.11

Muyaroah, S., \& Fajartia, M. (2017). Pengembangan Media Pembelajaran Berbasis Android dengan menggunakan Aplikasi Adobe Flash CS 6 pada Mata Pelajaran Biologi. Innovative Journal of Curriculum and Educational Technology, 6(2), 22-26. https://doi.org/10.15294/ijcet.v6i2.19336

Naimah, J., Winarni, D. S., \& Widiyawati, Y. (2019). Pengembangan Game Edukasi Science Adventure Untuk Meningkatkan Keterampilanpemecahan Masalah Siswa. Jurnal Pendidikan Sains Indonesia (Indonesian Journal of Science Education), 7(2), 91-100. https://doi.org/10.24815/jpsi.v7i2.14462

Nugraha, A. C., \& Hertanto, D. B. (2017). Rancang Bangun Game Edukasi Sebagai Media Pembelajaran Mata Kuliah Praktik Teknik Digital. Jurnal Edukasi Elektro, 1(1), 9298. https://doi.org/10.21831/jee.v1i1.15121

Pratama, R. A., \& Rahayu Sri Waskitoningtyas. (2020). GAME ANDROID "MENALAR" BERBASIS ADOBE ANIMATION CC. AKSIOMA: Jurnal Program Studi Pendidikan Matematika, 9(3), 617-630.

Putri, Y. F., \& Sumbawati, M. S. (2017). Pengembangan Aplikasi Buku Saku Berbasis Android Sebagai Media Pembelajaran Hukum Kesehatan di Akademi Farmasi Surabaya. It-Edu, 2(02), 22-23.

Ramdani, A., Jufri, A. W., \& Jamaluddin, J. (2020). Pengembangan Media Pembelajaran Berbasis Android pada Masa Pandemi Covid-19 untuk Meningkatkan Literasi Sains Peserta Didik. Jurnal Kependidikan: Jurnal Hasil Penelitian Dan Kajian Kepustakaan Di Bidang Pendidikan, Pengajaran Dan Pembelajaran, 6(3), 433. https://doi.org/10.33394/jk.v6i3.2924

Safitri, A. W., Pujiastuti, H., \& Sudiana, R. (2020). Pengembangan Game Edukasi dengan Konteks Kearifan Lokal Banten pada Materi Matriks. Journal of Medives : Journal of 
Mathematics Education IKIP Veteran Semarang, 4(2), 319. https://doi.org/10.31331/medivesveteran.v4i2.1171

Sejati, K. A. P., \& Koeswanti, H. D. (2020). Pengembangan Model Media Pembelajaran Berbasis PC Game Untuk Meningkatkan Kemampuan Pemecahan Masalah Materi Bangun Datar. Jurnal Cendekia: Jurnal Pendidikan Matematika, 4(2), 602-614. https://doi.org/10.31004/cendekia.v4i2.279

Sugiyarti, L., Arif, A., \& Mursalin. (2018). Pembelajaran Abad 21 di SD. Prosiding Seminar Dan Diskusi Nasional Pendidikan Dasar.

Sugiyono. (2014). Memahami Penelitian Kualitatif. Bandung: Alfabeta.

Virginiawan, \& Sitohang, S. (2020). Game Edukasi Pembelajaran Matematika Persamaan Linier Berbasis Android. Jurnal Comasie, 03(01).

Wahidin, U., \& Syaefuddin, A. (2018). Media Pendidikan Dalam Perspektif Pendidikan Islam. Edukasi Islami: Jurnal Pendidikan Islam, 7(01). https://doi.org/10.30868/ei.v7i01.222 